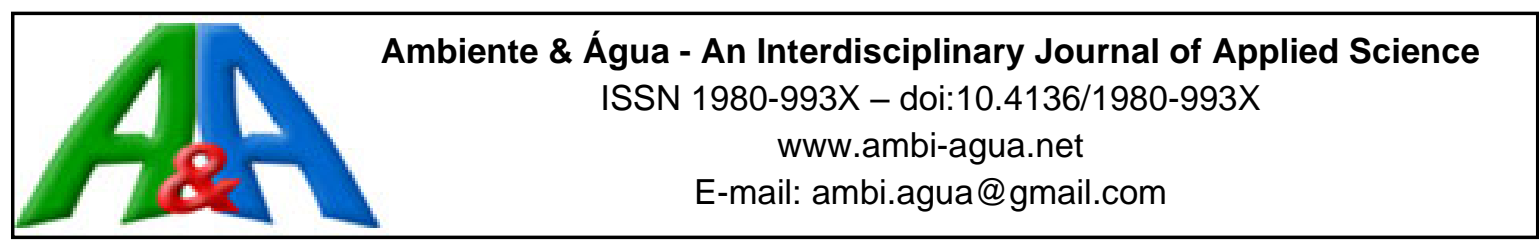

\title{
Calcined nepheline syenite powder increases potassium availability to corn
}

\author{
doi:10.4136/ambi-agua.2315
}

Received: 20 Nov. 2019; Accepted: 20 Dec. 2019

\begin{abstract}
Julio Cesar Raposo de Almeida ${ }^{1 *}$; Luiz Valério de Castro Carvalho ${ }^{1}$; Ana Aparecida da Silva Almeida²; João Luiz Gadioli ${ }^{1}$; Omar Vieira Villela ${ }^{3}$

${ }^{1}$ Departamento de Ciências Agrárias. Universidade de Taubaté (UNITAU), Est. Mun. Dr. José Luiz Cembranelli, n 5000, CEP: 12081-010, Taubaté, SP, Brazil. E-mail: luizvalerio@ mailcity.com, gadioli@ unitau.br ${ }^{2}$ Instituto Básico de Biociências (IBB). Universidade de Taubaté (UNITAU), Av. Tiradentes, n 500, CEP: 12030-180, Taubaté, SP, Brazil. E-mail: anaparecida.almeida@gmail.com

${ }^{3}$ Agência Paulista de Tecnologia dos Agronegócios (APTA), Av. Prof. Manoel César Ribeiro, n 1920 , CEP: 12400-970, Pindamonhangaba, SP, Brazil. E-mail: omar.villela@uol.com.br

"Corresponding author. E-mail: jcraposo@uol.com.br
\end{abstract}

\begin{abstract}
This research evaluated powdered nepheline syenite (NS) as a potassium source for corn. The treatments were different particle sizes and heating the NS with calcium chloride at $900^{\circ} \mathrm{C}$, and the samples were incubated in soil under controlled conditions before cropping. The experiment was conducted in a greenhouse using corn (Zea mays L.) plants cultivated in pots in a completely randomized $2 \times 3+2$ factorial block design with five replications. Five plants were growth in each pot with $5 \mathrm{~kg}$ of an Oxisol-Typic Hapludox soil for three successive 33day cropping periods. At the end of each cropping period the $\mathrm{K}$ contents of shoot dry matter and soil and were determined. There was no effect on shoot dry matter production ( $p>0.05)$. There was greater soil and dry matter K contents when heated NS was used, but for particle size. The treatments significantly affected $(\mathrm{p}<0.01)$ the $\mathrm{K}$ levels in the plants in the first crop. There was no residual effect on potassium content in the soil after the third crop ( $p>0.05)$. NS in natura has low solubility and does not provide potassium to plants while calcined rock powder works as a thermopotassium source.
\end{abstract}

Keywords: agromineral, calcination, remineralizer, rock.

\section{Pó de rocha de nefelina sienito calcinado aumenta a disponibilidade de potássio para o milho}

\section{RESUMO}

Este trabalho avaliou o uso do pó de nefelina sienito (NS) como fonte de potássio para o milho em função do tamanho das partículas e o tratamento térmico a $900{ }^{\circ} \mathrm{C}$ com cloreto de cálcio (calcinação). Os tratamentos foram incubados no solo em condições controladas antes do plantio. O experimento foi conduzido em casa de vegetação usando plantas de milho (Zea mays L.) cultivadas em vasos, em um delineamento fatorial $2 \mathrm{X} 3+2 \mathrm{em}$ blocos completamente casualizado, com cinco repetições. Foram realizados três cultivos consecutivos de 33 dias, sendo que em cada cultivo cada vaso com $5 \mathrm{~kg}$ de Latossolo Vermelho-Amarelo distrófico continha cinco plantas de milho. No final de cada período, foram determinados os teores de 
Julio Cesar Raposo de Almeida et al.

massa seca da parte aérea, teores de K no solo e na matéria seca da parte aérea. Não houve efeito dos tratamentos na produção de matéria seca da parte aérea $(\mathrm{P}>0,05)$. Maiores teores de $\mathrm{K}$ no solo e na matéria seca foram observados quando se utilizou o pó de rocha calcinado, independentemente do tamanho das partículas. Os tratamentos afetaram significativamente ( $\mathrm{P}$ $<0,01)$ os níveis de $K$ nas plantas na primeira safra. Não houve efeito residual no teor de potássio no solo após o terceiro cultivo $(\mathrm{P}>0,05)$. O pó de nefelina sienito in natura apresentou baixa solubilidade e não forneceu potássio às plantas, enquanto o pó de rocha calcinada funcionou como um termopotássio.

Palavras-chave: agromineral, calcinação, remineralizador, rocha.

\section{INTRODUCTION}

Brazilian agriculture is the world's largest consumer of fertilizers and one of the largest importers. In 2018 Brazil imported 10.5 million tons of potassium chloride $(\mathrm{KCl})$, the most commonly used source of potassium (GLOBALFERT, 2018). This demand for potassium (K) is met by imports from Canada, Belarus, Russia and Israel since the national fertilizer industry cannot supply the domestic market (Melamed et al., 2009; GLOBALFERT, 2018).

The use of rock powder as an alternative for soil fertilization, or as a complement to chemical fertilizers, is an important step towards sustainable development (Lapido-Loureiro and Ribeiro, 2009). Rock powder consists of finely ground rocks that are used as a nutrient source for plants (Resende et al., 2006; Cortes et al., 2010) and represents a practice that has been long-used and that has gained new impetus with the Law 12.890/2013 (Brasil, 2013, 2016). However, Martins et al. (2008) suggested the need to conduct regional studies in order to demonstrate the potential of these agrominerals in agriculture.

Present in a large number of rocks, potassium is a nutrient that is found in insoluble forms or is little soluble in water and is therefore difficult to be absorbed by plants (Nascimento and Lapido-Loureiro, 2004; Nascimento et al., 2005).

Nepheline syenite is a leucocratic feldspathic plutonic rock composed predominantly of the mineral nepheline $\left(\mathrm{Na}_{3} \mathrm{~K}\left(\mathrm{AlSiO}_{4}\right)_{4}\right)$, and free quartz, capable of releasing $\mathrm{K}$ at moments that are appropriate to the needs of plants (Reis, 2013, Jena et al., 2014).

However, the application of the nepheline syenite powder to soil has shown contrasting results, with positive effects on beans (Duarte, 2010), but with no effect on millet production (Santos, 2013).

Technological processes have been used to increase the reactivity and solubility of the elements present in rocks, either in pure form (in natura) or in mixtures, considering that the technical, economic and environmental viability should account for the residual effect of the availability of K and soil-plant requirements and relations (Oliveira et al., 2005; Luz et al., 2010).

Martins et al. (2008) reported that the granulometry of the rock is a factor that must be evaluated both in terms of efficiency in the industrial processing and the influence on the agronomic performance of the sources. In practice, the degree of comminution of the rock defines its viability for agricultural use, since smaller grains accelerate the dissolution of the rock and increase the availability of nutrients to the plants (Souza and Schneider, 2015).

The potassium present in nepheline syenite is intricately associated with different mineral phases present in the host rock. In this context, the calcination of nepheline syenite and dolomitic limestone resulted in an increase in agronomic efficiency up to 55\% in corn (Siqueira et al., 1985). Jena et al. (2014) used nepheline syenite with a particle size of less than $0.1 \mathrm{~mm}$ subjected to calcination $\left(900^{\circ} \mathrm{C}\right)$, which allowed for recovery of more than $99 \% \mathrm{~K}_{2} \mathrm{O}$ from the rock.

The aim of this work was to evaluate the treatment effects of granulometry and heating at $900^{\circ} \mathrm{C}$ of nepheline syenite powder with calcium chloride to measure potassium release to the soil for absorption by corn plants. 


\section{MATERIALS AND METHODS}

The nepheline syenite powder was obtained from Mineração Rio do Braço, a mining company in Lavrinhas, São Paulo, Brazil, and had the following chemical properties: $57.8 \%$ $\mathrm{SiO}_{2}, 19.9 \% \mathrm{Al}_{2} \mathrm{O}_{3}, 7.3 \% \mathrm{~K}_{2} \mathrm{O}, 6.9 \% \mathrm{Na}_{2} \mathrm{O}, 3.3 \% \mathrm{Fe}_{2} \mathrm{O}_{3}, 1.4 \% \mathrm{CaO}, 0.7 \% \mathrm{MgO}, 0.23 \% \mathrm{MnO}$, $0.12 \% \mathrm{P}_{2} \mathrm{O}_{5}$ and $0.8 \% \mathrm{TiO}_{2}$.

This product was evaluated for the effects of particle size and heat treatment with $\mathrm{CaCl}_{2}$. We used a completely randomized $2 \times 3+2$ factorial block design with five replications, to combine three particle sizes, small (S), medium (M) and large (L), in natura, and heating at $900^{\circ} \mathrm{C}$ with $\mathrm{CaCl}_{2}$ and 2 additional treatments, Control (zero rate) and $\mathrm{KCl}$ (Table 1).

The control did not receive potassium fertilizer, while the other treatments received equivalent to $100 \mathrm{~kg}$ of $\mathrm{K}_{2} \mathrm{O} \mathrm{ha}{ }^{-1}$. The treatments $\mathrm{SH}, \mathrm{MH}$ and $\mathrm{LH}$ represent the rock powder mixed with $\mathrm{CaCl}_{2}(55 \mathrm{~g}: 45 \mathrm{~g})$ heated at $900^{\circ} \mathrm{C}$ in a muffle furnace for 30 minutes (Figure 1).

Table 1. Treatments used in the experiment to evaluate the effect of NS powder particle size and heating with calcium chloride $\left(\mathrm{CaCl}_{2}\right)$ at $900{ }^{\circ} \mathrm{C}$.

\begin{tabular}{ccc}
\hline Treatments & Particle size & Rate $(\mathbf{g} /$ pot) \\
\hline Control (zero rate) & - & - \\
KCl & - & $0.43 \mathrm{~g} \mathrm{KCl}$ \\
Small $(\mathrm{S})$ & $<0.053 \mathrm{~mm}$ & $3.42 \mathrm{~g}$ rock powder \\
Medium $(\mathrm{M})$ & 0.053 to $0.149 \mathrm{~mm}$ & $3.42 \mathrm{~g}$ rock powder \\
Large $(\mathrm{L})$ & $>0.149 \mathrm{~mm}$ & 3.42 g rock powder \\
Small Heated $(\mathrm{SH})$ & $<0.053 \mathrm{~mm}$ & $5.15 \mathrm{~g}$ rock powder heated \\
Medium Heated $(\mathrm{MH})$ & 0.053 to $0.149 \mathrm{~mm}$ & $5.15 \mathrm{~g}$ rock powder heated \\
Large Heated $(\mathrm{LH})$ & $>0.149 \mathrm{~mm}$ & $5.15 \mathrm{~g}$ rock powder heated \\
\hline
\end{tabular}

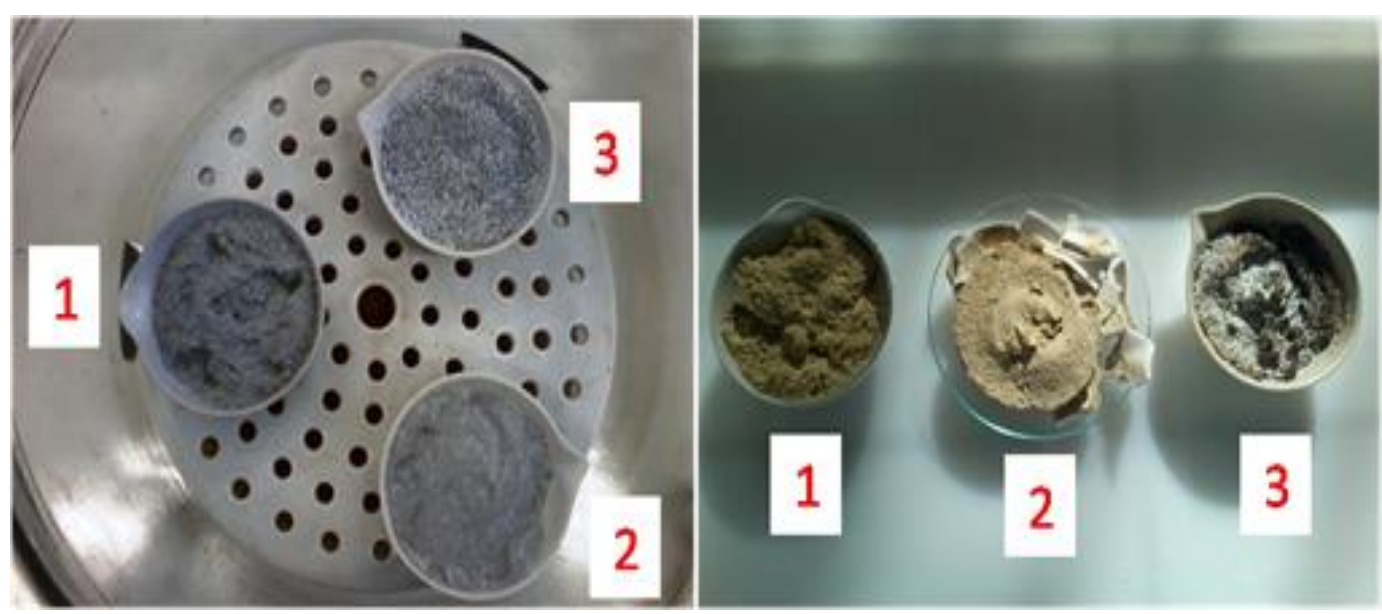

Figure 1. Capsules containing the powdered nepheline syenite and $\mathrm{CaCl}_{2}$ mixed in small (1), medium (2) and large (3), before (left) and after (right) muffle furnace heating.

The soil used in this experiment was collected at Fazenda Piloto da Universidade de Taubaté. It is a Latossolo Vermelho Amarelo distrófico according to Brazilian Soil Taxonomy (Santos et al., 2013), and is classified as an Oxisol-Typic Hapludox using the United States Soil Classification System (Soil Survey Staff, 2014) with K content of $1.6 \mathrm{mmol}_{\mathrm{c}} \mathrm{dm}^{-3}$ (Table 2).

We used 4L PVC pots with $5 \mathrm{~kg}$ of soil in each. The pots were internally lined with plastic to prevent nutrient losses. At the start of the experiment soil moisture based on the weight of the pots was restored to $70 \%$ of maximum capacity by the addition of distilled water, and then the treatments were applied and incubated for 47 days. After this incubation period, a soil sample from each pot was collected and the $\mathrm{Ca}, \mathrm{Mg}, \mathrm{K}$, and $\mathrm{H}+\mathrm{Al}$ contents were determined. Based on these results dolomitic limestone was applied to increase base saturation to $\mathrm{V}=70 \%$ 
(Table 3). At this time soil moisture was again restored to $70 \%$ of maximum capacity for a further 47 days of incubation.

Table 2. Soil chemical properties before application of treatments.

\begin{tabular}{|c|c|c|c|c|c|c|c|c|c|c|c|c|c|}
\hline $\mathbf{p H}$ & OM & $\mathbf{P}$ & $\mathbf{K}$ & Ca & Mg & $\mathbf{H}+\mathbf{A l}$ & SB & CEC & $\mathbf{V}$ & $\mathbf{C u}$ & $\mathbf{F e}$ & Mn & $\mathbf{Z n}$ \\
\hline$\left(\mathrm{CaCl}_{2}\right)$ & $\left(\mathrm{g} / \mathrm{dm}^{3}\right)$ & & & & mmol & $\left./ \mathbf{d m}^{3}\right)$ & & & $\%$ & & & & \\
\hline 4.3 & 21.0 & 3.0 & 1.6 & 6.0 & 2.0 & 36.0 & 9.6 & 45.6 & 21.0 & 0.6 & 60.0 & 4.0 & 0.8 \\
\hline
\end{tabular}

$\mathrm{pH}$ in $\mathbf{C a C l}_{2}$ at a ratio of $1: 2.5 \mathrm{v} / \mathrm{v} . \mathrm{Ca}^{2+} . \mathrm{Mg}^{2+}$ and $\mathrm{Al}^{3+}$ extracted with $\mathrm{KCl}$ solution $\left(1 \mathrm{~mol} \mathrm{~L}^{-1}\right) ; \mathrm{P}$ and $\mathrm{K}$ extracted with Mehlich ${ }^{-1} ; \mathrm{H}+\mathrm{Al}=\mathrm{SMP}$ buffer solution - $\mathrm{pH} 7.5 ; \mathrm{CEC}$ at $\mathrm{pH}$ 7.0. $\mathrm{SB}=$ sum of bases; $\mathrm{Cu}^{2+}, \mathrm{Mn}^{2+}$ and $\mathrm{Al}^{3+}$ extracted with DTPA solution $\left(1 \mathrm{~mol} \mathrm{~L}^{-1}\right)$.

Table 3. Dolomitic limestone incorporated into the soil per treatment (g/pot).

\begin{tabular}{cc}
\hline Treatments & Limestone $(\mathrm{g} / \mathrm{pot})$ \\
\hline Control (zero rate) & 10.6 \\
KCl & 9.6 \\
Small (S) & 9.3 \\
Medium (M) & 9.7 \\
Large (L) & 10.0 \\
Small Heated (SH) & 9.0 \\
Medium Heated (MH) & 8.3 \\
Large Heated (LH) & 9.9 \\
\hline
\end{tabular}

Fertilization was calculated in accordance with the recommendations for corn (Zea mays L.) (RAIJ et al., 1996). After the second incubation period each pot was fertilized with $0.38 \mathrm{~g}$ of ammonium sulfate and phosphorus using $0.83 \mathrm{~g}$ of simple superphosphate, equivalent to 30 $\mathrm{kg} / \mathrm{ha}$ of $\mathrm{N}$ and $60 \mathrm{~kg} / \mathrm{ha}$ of $\mathrm{P}_{2} \mathrm{O}_{5}$.

Three consecutive maize cropping periods were conducted using 5 plants per pot. The moisture of the soil was evaluated weekly by weighing the pots to estimate the irrigation volume required. Complementary topdressing fertilizer applications were done by adding $50 \mathrm{ml}$ of ammonium sulfate solution twice and $10 \mathrm{ml}$ of ammonium phosphate solution once per culture.

The plants were harvested every 33 days after sowing at a height of $1 \mathrm{~cm}$ from the soil and were dried at $65^{\circ} \mathrm{C}$ for $72 \mathrm{~h}$. The dry matter (DM) variable was calculated as the sum of the weight $(\mathrm{g})$ of the five corn plants in each pot. The $\mathrm{K}$ was extracted from the DM through nitric perchloric digestion and determined by flame photometry. The "total $\mathrm{K}$ absorbed" variable was obtained as the $\mathrm{K}$ content multiplied by the DM produced.

The agronomic efficiency (AE) was calculated as the percentage ratio between $\mathrm{K}$ absorbed as result of applied treatments minus the $\mathrm{K}$ absorbed in the control treatment (Equation 1).

$$
A E(\%)=\frac{\mathrm{K}_{\text {treatment }}-\mathrm{K}_{\text {Control }}}{\mathrm{K}_{\mathrm{KCl}}-\mathrm{K}_{\text {Control }}} * 100
$$

The results were submitted to analysis of variance and in the case of a significant $\mathrm{F}$ Test ( $p<0.05)$ means were compared by Tukey's test $(5 \%)$ using the SISVAR software (Ferreira, 2014). 


\section{RESULTS AND DISCUSSION}

\subsection{NS powder incubation in soil}

The effects of treatments on mean soil $\mathrm{K}$ content were significant in both incubation periods $(\mathrm{p}<0.01)$. The mean comparison test for the effects of the treatments in each period confirmed the superiority of the conventional $\mathrm{KCl}$ in terms of $\mathrm{K}$ release (Table 4).

Table 4. Potassium contents $\left(\mathrm{mmol}_{\mathrm{c}} \mathrm{dm}^{-3}\right)$ in an Oxisol-Typic Hapludox incubated with NS powder in natura and heated with $\mathrm{CaCl}_{2}$ in a muffle furnace after two incubation periods.

\begin{tabular}{ccccc}
\hline \multirow{2}{*}{ Treatments } & \multicolumn{4}{c}{ K content in soil $\left(\mathrm{mmol}_{\mathrm{c}} \mathrm{dm}^{-3}\right)$} \\
\cline { 2 - 5 } & 47 days after incubation & 94 days after incubation & \\
\hline Control (zero rate) & 2.44 & $\mathrm{c}$ & 2.64 & $\mathrm{~d}$ \\
KCl & 4.19 & $\mathrm{a}$ & 3.52 & $\mathrm{a}$ \\
Small (S) & 2.64 & $\mathrm{c}$ & 2.60 & $\mathrm{~d}$ \\
Medium (M) & 2.56 & $\mathrm{c}$ & 2.72 & $\mathrm{~cd}$ \\
Large (L) & 2.62 & $\mathrm{c}$ & 2.70 & $\mathrm{~cd}$ \\
Small Heated (SH) & 3.22 & $\mathrm{~b}$ & 3.04 & $\mathrm{~b}$ \\
Medium Heated (MH) & 3.05 & $\mathrm{~b}$ & 2.99 & $\mathrm{bc}$ \\
Large Heated (LH) & 3.23 & $\mathrm{~b}$ & 3.13 & $\mathrm{~b}$ \\
\hline CV (\%) & 5.11 & & 5.05 & \\
\hline
\end{tabular}

*Means followed by the same letters in a column do not differ significantly by the Tukey test $(\mathrm{p}<0.05)$. CV = coefficient of variation.

During both treatment periods, regardless of the particle size (S, M and L) NS in natura did not promote significant $\mathrm{K}$ release compared to the control. The potassium present in nepheline syenite is intricately associated with different mineral phases present in the host rock (Jena et al., 2014) resulting in the low solubility of K present in NS in natura.

However, treatments with heated NS with calcium chloride at $900{ }^{\circ} \mathrm{C}$ promoted higher soil $\mathrm{K}$ contents. These results demonstrate the efficiency of the heating with calcium chloride in increasing the availability of $\mathrm{K}$ from nepheline syenite. Jena et al. (2014) who used this calcium chloride heat treatment at $900^{\circ} \mathrm{C}$ reported that it was possible recover $99.6 \%$ of the potassium at $45 \% \mathrm{CaCl}_{2}$.

These results are similar to those observed by Siqueira and Guedes (1986) who studied mixtures composed of NS + limestone heated at 900 and $1,150{ }^{\circ} \mathrm{C}$ which increased $\mathrm{K}$ solubilization by $50 \%$.

Treatments S, M and L and the Control promoted an increase in soil $\mathrm{K}$ contents after the second incubation period. In contrast, there was a decline in soil $\mathrm{K}$ contents in treatments with heated rock powder, as well as for $\mathrm{KCl}$.

\subsection{Dry matter (DM)}

None of the treatments resulted in significant effects on DM production $(p>0.05)$ in the three successive crops (Table 5).

There was a tendency to decrease production with each crop. The DM of the first crop was $17.1 \mathrm{~g}$ per pot, surpassing by $31.5 \%$ the average in the second crop (13 g) and 3.3 times that of the third crop $(4 \mathrm{~g})$. Thus, the first crop corresponded on average to $50.15 \%$ of all biomass, possibly related to the decrease of soil K contents. The reduced effect of NS is due to its low K-supplying capacity even by the third cropping. These data support earlier studies of Siqueira et al. (1985) and Faquin et al. (1987). 
Table 5. Dry matter produced by corn plants in three successive cropping periods on an Oxisol-Typic Hapludox with NS powder in natura or NS heated with $\mathrm{CaCl}_{2}$ in a muffle furnace.

\begin{tabular}{ccccc}
\hline \multirow{2}{*}{ Treatments } & $1^{\text {St }}$ Crop & $2^{\text {nd }}$ Crop & $3^{\text {rd }}$ Crop & Total \\
\cline { 2 - 5 } & \multicolumn{4}{c}{ g per pot } \\
\hline Control (zero rate) & 16.9 & 13.1 & 4.6 & 34.6 \\
KCl & 17.7 & 13.8 & 3.8 & 35.3 \\
Small (S) & 16.9 & 12.7 & 3.4 & 33.1 \\
Medium (M) & 17.8 & 12.7 & 3.5 & 34.0 \\
Large (L) & 16.5 & 12.9 & 4.2 & 33.6 \\
Small Heated (SH) & 17.6 & 13.2 & 3.4 & 34.2 \\
Medium Heated (MH) & 17.2 & 12.3 & 4.0 & 33.5 \\
Large Heated (LH) & 16.3 & 13.6 & 4.6 & 34.5 \\
\hline CV (\%) & 9.4 & 11.3 & 26.9 & 6.6 \\
\hline
\end{tabular}

$\mathrm{CV}=$ coefficient of variation.

The plant $K$ concentrations varied significantly in the first $(\mathrm{p}<0.01)$ and second $(\mathrm{p}<0.05)$ but not in the third ( $\mathrm{p}>0.05$ ) cropping period (Table 6).

In the first crop, the results of treatments $\mathrm{SH}, \mathrm{MH}$ and $\mathrm{LH}$ were equivalent to the $\mathrm{KCl}$ treatment demonstrating release of $\mathrm{K}$ to corn plants. In the second crop, the $\mathrm{KCl}$ treatment still maintained its superiority although it did not differ from the treatments $\mathrm{L}, \mathrm{SH}, \mathrm{MH}, \mathrm{LH}$. The treatments with heated NS did not differ from NS in natura and Control.

Table 6. Effects of NS in natura and heated with $\mathrm{CaCl}_{2}$ in a muffle furnace on plant $\mathrm{K}$ concentrations $\left(\mathrm{g} \mathrm{kg}^{-1}\right)$ in three successive cropping periods on an Oxisol-Typic Hapludox.

\begin{tabular}{cccccc}
\hline \multirow{2}{*}{ Treatments } & $1^{\text {St }}$ Crop & \multicolumn{3}{c}{$2^{\text {nd }}$ Crop } & $3^{\text {rd }}$ Crop \\
\cline { 2 - 6 } & \multicolumn{5}{c}{$\mathrm{g} \mathrm{kg}^{-1}$} \\
\hline Control (zero rate) & 18.2 & $\mathrm{~b}$ & 7.5 & $\mathrm{~b}$ & 5.7 \\
KCl & 24.3 & $\mathrm{a}$ & 10.4 & $\mathrm{a}$ & 7.2 \\
Small (S) & 18.4 & $\mathrm{~b}$ & 8.0 & $\mathrm{~b}$ & 5.9 \\
Medium (M) & 18.4 & $\mathrm{~b}$ & 7.5 & $\mathrm{~b}$ & 5.9 \\
Large (L) & 18.9 & $\mathrm{~b}$ & 8.3 & $\mathrm{ab}$ & 6.3 \\
Small Heated (SH) & 24.2 & $\mathrm{a}$ & 8.4 & $\mathrm{ab}$ & 7.5 \\
Medium Heated (MH) & 22.8 & $\mathrm{a}$ & 8.2 & $\mathrm{ab}$ & 6.9 \\
Large Heated (LH) & 22.7 & $\mathrm{a}$ & 8.2 & $\mathrm{ab}$ & 6.6 \\
\hline CV (\%) & 7.7 & & 13.2 & & 15.9 \\
\hline
\end{tabular}

*Means followed by the same letters in a column do not differ significantly by the Tukey test $(\mathrm{p}<0.05)$. $=$ coefficient of variation.

The effects of NS powder on K absorbed by the plants were significant in the first and the second crops and at the end of the three cropping periods ( $\mathrm{p}<0.01)$, but no significant effect was observed in the third crop ( $\mathrm{p}>0.05$ ) (Table 7). In the first crop, the $\mathrm{KCl}$ treatment had higher absorbed K (429.5 mg / pot) and did not differ from the heated rock powder treatments that accumulated 373.3 and 425.6/pot. The $\mathrm{K}$ uptake of the plants was lower in the control and NS in natura (S, M and L) treatments. In the second crop the $\mathrm{KCl}$ treatment promoted the highest K absorption (142.5 mg/pot) differing from the other treatments that accumulated about 95.6 to $109.6 \mathrm{mg} / \mathrm{pot}$. 
Table 7. Potassium absorbed by corn plants in three successive cropping periods in response to NS powder with different granulometry in natura and heated with $\mathrm{CaCl}_{2}$ at $900^{\circ} \mathrm{C}$ on an Oxisol-Typic Hapludox.

\begin{tabular}{|c|c|c|c|c|c|c|c|}
\hline \multirow{2}{*}{ Treatments } & $1^{\text {St }}$ Crop & & $2^{\text {nd }}$ Crop & & $3^{\text {rd }}$ Crop & total & \\
\hline & \multicolumn{7}{|c|}{$\mathrm{mg} /$ pot } \\
\hline Control (zero rate) & 308.9 & $\mathrm{~b}$ & 98.1 & B & 26.4 & 433.4 & $\mathrm{~b}$ \\
\hline $\mathrm{KCl}$ & 429.5 & $\mathrm{a}$ & 142.5 & a & 27.2 & 599.2 & $\mathrm{a}$ \\
\hline Small (S) & 311.7 & $\mathrm{~b}$ & 100.8 & $\mathrm{~b}$ & 20.1 & 432.7 & $\mathrm{~b}$ \\
\hline Medium (M) & 326.5 & $a b$ & 95.6 & $\mathrm{~b}$ & 19.7 & 441.8 & $\mathrm{~b}$ \\
\hline Large (L) & 312.4 & $\mathrm{~b}$ & 107.9 & $\mathrm{~b}$ & 26.3 & 446.6 & $\mathrm{~b}$ \\
\hline Small Heated (SH) & 425.6 & $\mathrm{a}$ & 107.4 & $\mathrm{~b}$ & 24.6 & 557.6 & a \\
\hline Medium Heated (MH) & 391.2 & $a b$ & 98.2 & $\mathrm{~b}$ & 27.0 & 516.5 & $a b$ \\
\hline Large Heated (LH) & 373.3 & $\mathrm{ab}$ & 109.6 & $\mathrm{~b}$ & 29.7 & 512.7 & $a b$ \\
\hline $\mathrm{CV}(\%)$ & 13.9 & & 8.6 & & 24.2 & 9.4 & \\
\hline
\end{tabular}

*Means followed by the same letters in a column do not differ significantly by the Tukey test $(\mathrm{p}<0.05)$. CV = coefficient of variation.

Mancuso et al. (2014) studied coffee plant nutrition and fertilization efficiency under phonolite rock powder concluded that rock powder can be used as a nutrient source, proving efficient for K supply to coffee.

Throughout the three crops the corn plants on the NS heated treatments $\mathrm{SH}, \mathrm{MH}$ and $\mathrm{LH}$ absorbed $\mathrm{K}$ as well as occurred in the $\mathrm{KCl}$ treatment. This demonstrates the efficiency of the processed rock powder mixed with $\mathrm{CaCl}_{2}$ heated at $900^{\circ} \mathrm{C}$ in a muffle furnace for 30 minutes in increasing the availability of this nutrient to plants. The application of NS in natura was not effective, as it did not differ from the control treatment.

\subsection{Agronomic efficiency (AE)}

The NS heated with $\mathrm{CaCl}_{2}$ was more efficient than NS in natura to supply $\mathrm{K}$ to corn plants (Table 8). According to Jena et al. (2014), the K present in nepheline syenite is intricately associated with different mineral phases present in the rock. Thus, it seems that NS in natura can't be used as a K source for corn because agronomic efficiency depends on the K solubility of the rock, and thus materials in which $\mathrm{K}$ is bound to minerals that are more easily solubilized will show greater efficiency.

In this case the degree of comminution of the rock associated with heating at $900{ }^{\circ} \mathrm{C}$ with $\mathrm{CaCl}_{2}$ defined the viability for its agricultural use since the treatment with smaller grains (< $0.053 \mathrm{~mm}$ ) that are heated seems accelerate the dissolution of the rock and increase the availability of K for the plants. Souza and Schneider (2015) evaluated the extraction of K from NS using an alkaline agent and also noted this same relationship.

Table 8. Agronomic efficiency (AE) of treatments with NS for corn plants.

\begin{tabular}{cc}
\hline Treatments & $\mathrm{AE}$ \\
\hline Control (zero rate) & 0.0 \\
KCl & 100 \\
Small (S) & -0.5 \\
Medium (M) & 5.1 \\
Large (L) & 7.9 \\
Small Heated (SH) & 74.9 \\
Medium Heated (MH) & 50.1 \\
Large Heated (LH) & 47.8 \\
\hline
\end{tabular}

Rev. Ambient. Água vol. 7 (supplement) - Taubaté 2019 


\section{CONCLUSIONS}

The study showed that nepheline syenite powder calcined with $\mathrm{CaCl}_{2}$ at $900{ }^{\circ} \mathrm{C}$ increases the supply of $\mathrm{K}$ to corn plants with greater agronomic efficiency for particles smaller than $0.0053 \mathrm{~mm}$ in diameter. Likewise, nepheline syenite powder in natura has low solubility and does not provide potassium to corn plants.

\section{ACKNOWLEDGEMENTS}

The authors are grateful to Mineração Rio do Braço for financial support.

\section{REFERENCES}

BRASIL. Lei $\mathrm{n}^{\circ} 12.890$ de 10 de dezembro de 2013. Available at: < http://www.planalto.gov.br/ccivil_03/_Ato2011-2014/2013/Lei/L12890.htm\#art2>.

BRASIL. Ministério da Agricultura. Pecuária e Abastecimento (MAPA). Instrução Normativa $\mathbf{n}^{\mathbf{0}} \mathbf{5}$. de 10 de março de 2016. Available at: < http://www.agricultura.gov.br/assuntos/insumos-agropecuarios/insumosagricolas/fertilizantes/legislacao/in-5-de-10-3-16-remineralizadores-e-substratos-paraplantas.pdf>

CORTES. G.P.; FERREIRA. R.C.; CORTES. G.P.; RAMPAZZO. L. \& FERREIRA. L.C. Fonolito como substituto do cloreto de potássio e/ou outras fontes de potássio na agricultura e pecuária do Brasil. In: CONGRESSO BRASILEIRO DE ROCHAGEM. $1 .$, Planaltina. 2010. Proceedings[...] Planaltina. Embrapa Cerrados. 2010. p.75-86.

DUARTE. W. M. Potencial das rochas flogopitito, granito e sienito na disponibilização de potássio em solos. 2010. 43 f. Dissertação (Mestrado) - Centro de Ciências Agroveterinárias. Universidade do Estado de Santa Catarina. Lages. 2010.

FAQUIN. V.; KINJO. T.; MALAVOLTA. E. Efeito do tratamento térmico da mistura de sienito nefelínico com calcário dolomítico na disponibilidade de potássio ao milho, em solo sob cerrado. Revista Brasileira de Ciência do Solo, n. 11, p. 221-228, 1987.

FERREIRA, D. F. Sisvar: a Guide for its Bootstrap procedures in multiple comparisons. Ciênc. Agrotec., Lavras, v.38, n.2, p. 109-112, 2014.

GLOBALFERT. Boletins Informativos. Available at: <https://www.globalfert.com.br/boletins/volume-de-importacao-de-fertilizantes-nobrasil-em-2018/>

JENA. S. K.; DHAWAN. N.; RAO. D.S.; MISRA. P. K.; MISHRA. B. K.; DAS. B. Studies on extraction of potassium values from nepheline syenite. International Journal of Mineral Processing. n. 133, p.13-22, 2014.

LAPIDO-LOUREIRO. F. E.; RIBEIRO. R. C. C.. Fertilização natural: rochagem, agricultura orgânica e plantio direto. Breve síntese conceitual. In: LAPIDOLOUREIRO. F. E.; MELAMED. R.; FIGUEIREDO NETO. J. Fertilizantes: agroindústria \& sustentabilidade. Rio de Janeiro: CETEM. 2009. 
LUZ. A. B.; LAPIDO-LOUREIRO. F. E.; SAMPAIO. J. A.; CASTILHOS. Z. C.; BEZERRA. M. S. Rochas, minerais e rotas tecnológicas para a produção de fertilizantes alternativos. In: FERNANDES. F. R. C.; LUZ. A. B.; CASTILHOS. Z. C. (Eds). Agrominerais para o Brasil. Rio de Janeiro: CETEM/MCT. p. 61-88. 2010.

MANCUSO, M.C.; SORATTO, R.P.; CRUSCIOL, C.A.C.; CASTRO, G.S.A. Effect of potassium sources and rates on arabica coffee yield, nutrition, and macronutrient export. Rev. Bras. Ciênc. Solo, Viçosa, v. 38, n. 5, p. 1448-1456, 2014.

MARTINS. E. S.; OLIVEIRA. C. G.; RESENDE. A. V.; MATOS. M. S. F. Agrominerais rochas silicáticas como fontes minerais alternativas de potássio para a agricultura. In: LUZ. A. B.; LINS. F. A. F. (Eds). Rochas \& minerais industriais: usos e especificações. 2 ed. revisada e ampliada. Rio de Janeiro: CETEM. p. 205-221. 2008.

MELAMED. R.; GASPAR. J.C.; MIEKELEY. N. Pó-de-rocha como fertilizante alternativo para sistemas de produção sustentáveis em solos tropicais. In: LAPIDO-LOUREIRO. F.E.V.; MELAMED. R. \& FIGUEIREDO NETO. J. eds. Fertilizantes: Agroindústria e sustentabilidade. Rio de Janeiro. CETEM/MCT. p.385-395. 2009.

NASCIMENTO, M.; LAPIDO-LOUREIRO, F. E. Fertilizantes e Sustentabilidade: o potássio na agricultura brasileira, fontes e rotas alternativas. Rio de Janeiro: CETEM, 2004. (Série Estudos e Documentos, 61).

NASCIMENTO, M.; MONTE, M. B. DE M.; LOUREIRO. F. E. L. Potássio In: Rocha e Minerais Industriais Editores: LUZ, A. B. DA; LINS, F. A. F. Rio de janeiro, RJ: CETEM. p.173-200. 2005.

OLIVEIRA. F. A. de; CASTRO. C.; SALINET. L. H.; VERONESI. C. O. Rochas brasileiras como fontes alternativas de potássio para uso em sistemas agropecuários. In: Reunião nacional de pesquisa de girassol. XVI. Simpósio nacional sobre a cultura do girassol. IV. 2005. Londrina. Anais... Londrina: Embrapa. p. 40-43. 2005.

RAIJ, B van.; CANTARELlA, H.; QUAGGIO, J. A.; FURLANI, A. M. C. (Eds). Boletim técnico 100: recomendações de adubação e calagem para o Estado de São Paulo. 2 ed. Campinas: IAC, 1996.

REIS, D. N. dos. Mineralogia, química, eficiência agronômica e tecnologias de solubilização de agrominerais fontes de potássio. 2013. 137 p. Tese (Doutorado). Universidade de Lavras. Lavras: UFLA, 2013.

RESENDE. A.V.; MARTINS. E.S.; OLIVEIRA. C.G.; SENA. M.C.; MACHADO. C.T.T.; KINPARA. D.I. \& OLIVEIRA FILHO. E.C. Suprimento de potássio e pesquisa de uso de rochas "in natura" na agricultura brasileira. Esp. Geogr. v.9, p.19-42. 2006.

SANTOS. H.G.; JACOMINE. P.K.T.; ANJOS. L.H.C.; OLIVEIRA. V.A.; LUBRERAS. J.F.; COELHO. M.R.; ALMEIDA. J.A.; CUNHA. T.J.F.; OLIVEIRA. J.B. (Eds.) Sistema Brasileiro de Classificação de Solos (3 ed.). Embrapa. Brasília. 353 p. 2013.

SIQUEIRA. J.O. \& GUEDES. G.A.A. Efeito do tratamento térmico na eficiência agronômica do sienito nefelínico. Pesquisa Agropecuária Brasileira, Brasília, v.21, p.481-488. 1986.

SIQUEIRA. J.O.; GUEDES. G.A.A.; RIBEIRO. M.A.V. Disponibilidade do potássio do sienito nefelínico de Poços de Caldas. avaliada em cultivos sucessivos com milho. Pesquisa Agropecuária Brasileira, v. 20, p.299-307. 1985. 
SOIL SURVEY STAFF. Keys to Soil Taxonomy (12 ed.). USDA-Natural Resources Conservation Service. Washington. D.C. 360 p. 2014.

SOUZA. I.C.A.; SCHNEIDER. C.L. Avaliação da rocha nefelina sienito para aplicação na rochagem. extração de potássio a partir de um agente alcalino. In: Jornada do Programa de Capacitação Interna do CETEM. 04. Rio de Janeiro. Anais. CETEM/MCTI. 2015. 